\title{
KONSEP ECOLOGICAL CITY DALAM KERANGKA KONSEP EKOLOGI KOTA DAN KOTA BERKELANJUTAN
}

\author{
Enni Lindia Mayona \\ Sekolah Arsitektur, Perencanaan dan Pengembangan Kebijakan Institut Teknologi Bandung \\ Penulis Korespondensi e-mail:elindamayona68@gmail.com
}

\begin{abstract}
City growth that continues to occur is unavoidable and affects the environment, so an ecological approach is needed to overcome it. One of the city concepts that has developed along with the historical perspective of urban ecology is the ecological city (ecocity). In the development of ecocity in several countries that carry the theme of sustainability city, both practice and concept do not explain the "process" to achieve the city's environmental sustainability goals. The purpose of this paper is to examine the theoretical position of the ecological city concept within the framework of urban ecology and sustainable cities. The method used is a literature review based on the development of the concept of ecocity, urban ecology and sustainable city. Based on the results of the study, it shows that in the urban ecology approach, ecocity can be concluded as a concept that balances the city's metabolism (ecology of cities) through the independence of the structure and function of the ecosystem where humans play a role in determining the process of adaptation and urban development. In the concept of a sustainable city along with the development of eco-form which represents ecological considerations in urban and community spaces, it shows that urban form is one of the elements that can be intervened in achieving sustainable city goals. Ecocity as an eco-form is in the challenge of conflict between aspects of the social environment where the conflict that occurs has shifted from development conflict to green conflict in a sustainable prism. The results of the study show that in the process of managing an environmentally sound city environment (ecocity) it is necessary to consider the integration of humans as social aspects in interaction with ecosystems (social-ecology) in city metabolism as the basis for providing ecosystem services and urban green infrastructure.

Keywords: ecological city, city ecology, sustainable city, city metabolism
\end{abstract}

\begin{abstract}
ABSTRAK
Pertumbuhan kota yang terus terjadi tidak dapat dihindari dan berpengaruh terhadap lingkungan, sehingga dibutuhkan pendekatan ekologi untuk mengatasinya. Salah satu konsep kota yang berkembang seiring dengan perspektif sejarah ekologi kota (urban ecology) adalah ecological city (ecocity). Pada perkembangan ecocity di beberapa negara yang mengusung tema kota keberlanjutan baik praktek maupun konsep tidak menjelaskan "proses" untuk mencapai tujuan keberlanjutan lingkungan kota tersebut. Tujuan makalah ini adalah mengkaji kedudukan secara teoritis konsep ecological city dalam kerangka ekologi kota (urban ecology) dan kota berkelanjutan (sustainability city). Metode yang digunakan adalah review literatur berdasarkan perkembangan konsep ecocity, urban ecology dan sustainable city. Berdasarkan hasil kajian menunjukkan dalam pendekatan urban ecology, ecocity dapat disimpulkan sebagai konsep yang menyeimbangkan metabolisme kota (ecology of cities) melalui kemandirian struktur dan fungsi ekosistem dimana manusia berperan di dalam menentukan proses adaptasi dan perkembangan kota. Dalam konsep kota berkelanjutan seiring dengan perkembangan eco-form yang merepresentasikan pertimbangan ekologi di dalam ruang kota dan komunitas menunjukkan bentuk kota (urban form) merupakan salah satu unsur yang dapat diintervensi di dalam mencapai tujuan kota yang berkelanjutan. Ecocity sebagai eco-form berada di dalam tantangan konflik antara aspek lingkungan sosial dimana konflik yang terjadi mengalami pergeseran dari development conflict ke arah green conflict di dalam prisma berkelanjutan. Hasil kajian menunjukkan di dalam proses pengelolaan lingkungan kota yang berwawasan lingkungan (ecocity) perlu mempertimbangkan integrasi manusia sebagai aspek sosial dalam interaksi dengan ekosistem (sosial-ekologi) di dalam metabolisme kota sebagai dasar di dalam penyediaan ecosystem services dan infrastruktur hijau perkotaan.

Kata Kunci : ecological city, ekologi kota, kota berkelanjutan, metabolisme kota
\end{abstract}




\section{PENDAHULUAN}

Kota merupakan pusat aktivitas yang memiliki tingkat konsumsi sumber daya alam tinggi sehingga berkontribusi besar terhadap isu-isu lingkungan global. Kota dalam perspektif lingkungan dianggap sebagai masalah ekologis karena berkaitan dengan ketidakseimbangan antara kebutuhan dan penyediaan sumber daya alam. Dalam ilmu lingkungan, perencanaan kota merupakan bagian yang harus terintegrasi dengan perencanaan lingkungan untuk mencapai pembangunan berkelanjutan.

Di dalam menghadapi perkembangan tersebut dan tantangan kota masa depan, terdapat beberapa tahapan yang harus dipahami sehingga dapat diantisipasi dalam proses perencanaan kota. Perkembangan kota berdasarkan World Economic Forum (WEF, 2017) terbagi atas 4 (empat) tahapan seiring dengan semakin kompleksnya aspek dan pendekatan yang harus dipertimbangkan yaitu rudimentary (kebutuhan dasar dan akses kepada masyarakat miskin), functional (penggunaan teknologi untuk efisiensi energi, kohesi masyarakat dan pola reuse recycling), integrated (kondisi dan aspirasi sosial), serta scalable (proses adaptasi cepat dan pendekatan terintegrasi). Perencanaan kota di abad 21 menjadi tonggak penting pergeseran keilmuan perencanaan kota yang bersifat klasik kepada keilmuan yang lebih tanggap terhadap perkembangan teknologi, inovatif serta adanya tujuan pembangunan global (SDGs) (Sutriadi, 2018). Oleh karena itu pendekatan pembangunan kota berkelanjutan dibutuhkan untuk mengatasi perkembangan kawasan perkotaan di masa mendatang berkaitan dengan tantangan dan perkembangan baik makna maupun pendekatan kota dan lingkungan kota.

Pergeseran makna kota dapat dilihat berdasarkan pergeseran isu-isu lingkungan perkotaan dan pergeseran studi ekologi kota (Mayona, 2021):

1. Pergeseran isu lingkungan kota dapat diidentifikasi melalui faktor-faktor lingkungan yang berpengaruh mulai dari desain kota berbasis ekologi pada masa 1880-1990 yang menitikberatkan city design berupa desain arsitektur klasik, dan taman publik menjadi pengetahuan tentang integrated methodology untuk sustainable design dan kesadaran penerapan teknologi dalam ecological design pada abad 21. Faktor-faktor lingkungan tersebut berkembang seiring dengan upaya perbaikan sanitasi atau kesehatan lingkungan (isu brown), upaya mengatasi pencemaran industri (isu grey) serta upaya yang berfokus pada deforestasi, penipisan sumber daya, pemanasan global, keanekaragaman hayati, dan polusi (isu green). 
2. Pada pergeseran konsep ekologi kota, kota tidak lagi dipandang sebagai organisme dengan siklus linier-klimaks-mapan namun sebagai ekosistem yang memiliki siklus dinamis dan kompleks. Makna kota sebagai ekosistem hibrida semakin penting mempertimbangkan manusia sebagai komponen dominan. Oleh karena itu pertimbangan pola ekologi manusia untuk merencanakan kota secara efektif mampu meningkatkan daya adaptif manusia terhadap perubahan tantangan ekologis kota.

Pendekatan baru dalam merencana kota sangat penting untuk memahami proses kota yang semakin kompleks. Pergeseran makna kota berdasarkan perspektif lingkungan memberikan implikasi berupa kebutuhan peningkatan pemahaman dan keterampilan pendekatan baru seorang perencana kota. Pendekatan/bentuk kota berlandaskan ekologi, integrasi manusia dan ekologi dalam konteks perkotaan yang berbeda secara ruang dan waktu semakin penting untuk dikaji di masa mendatang sebagai upaya menghadapi pergeseran makna kota tersebut dan menghadapi kondisi lingkungan sebagai elemen yang terbatas ketersediaannya.

Salah satu model pembangunan kota yang menitikberatkan pada makna lingkungan adalah konsep ecological city atau seringkali dikenal dengan ecocity. Perkembangan ecocity dari sisi praktek ditandai oleh perkembangan inovasi teknologi praktis dan bentuk-bentuk implementasi yang tersebar di berbagai wilayah secara global. Praktek-praktek tersebut menunjukkan tidak ada model penerapan yang beragam, meluasnya keterlibatan aktor baru melalui berbagai bentuk kemitraan publik-swasta (Joss et al., 2011) serta dari segi kebijakan menunjukkan adanya international knowledge transfer, carbon discourse, smart technology dan environmental modernisation (Joss et al., 2013). Dalam konteks praktek Asia menunjukkan dominasi bentuk implementasi ecocity pada pembangunan retrofit dan new build dengan aspek utama teknologi dan international knowledge yang terjadi melalui keterlibatan private firms.

Pada konteks Indonesia konsep ecocity diterapkan dalam bentuk Eco2cities di lima kota besar yaitu Jakarta, Surabaya, Balikpapan, Makasar dan Palembang. Tujuan Eco2cities adalah membangun sinergitas dan interdependensi ekologi dan keberlanjutan ekonomi serta kemampuan yang saling mendukung dalam konteks perkotaan (WEF, 2017). Tipe Pembangunan yang dilakukan berupa retrofit dengan fokus pembangunan yang berbeda yaitu transportasi dan penanganan banjir di Jakarta, ruang terbuka hijau (RTH) dan pengelolaan sampah di Surabaya, pantai dan 
drainase di Makasar, serta kampung ramah lingkungan dan pengelolaan limbah industri di Palembang. Pelaksanaan di Indonesia ini hampir sama dengan konteks negara-negara Asia lainnya menunjukkan aspek utama teknologi dan international knowledge yang terjadi melalui keterlibatan private firms dalam mencapai keberlanjutan ekonomi. Fenomena penerapan eco-city dalam skala internasional menunjukkan bahwa konsep tersebut digalakkan di beberapa negara dalam rangka mencapai pembangunan perkotaan yang berkelanjutan. Namun dalam penerapan tersebut belum menjelaskan kedudukan dan proses mencapai konsep keberlanjutan tersebut. Oleh karena itu paper ini bertujuan untuk mengkaji kedudukan konsep ecological city (ecocity) dalam konsep ekologi kota dan kota berkelanjutan. Hasil dari kajian ini diharapkan dapat memberikan gambaran pendekatan perencanaan kota yang sesuai dengan konseptualisasi kota berkaitan dengan aspek lingkungan perkotaan.

\section{METODE}

Metode yang digunakan adalah review literatur berdasarkan perkembangan konsep ecocity, urban ecology dan sustainable city. Pendekatan yang dilakukan adalah semisystematic review. Semi-systematic review atau naratif adalah tinjauan yang dirancang untuk topik yang telah terkonsep secara berbeda dan dipelajari oleh berbagai kelompok peneliti dalam berbagai disiplin ilmu sebagai upaya mengatasi kendala proses tinjauan sistematis penuh (Wong et al., 2013). Pendekatan ini meninjau setiap artikel yang relevan dengan topik dengan cara melihat bagaimana penelitian dalam bidang yang dipilih telah berkembang dari waktu ke waktu dan memiliki implikasi terhadap topik topik yang dipelajari melalui meta-narasi. Analisis yang digunakan berupa analisis tematik atau konten berupa teknik yang digunakan dan dapat didefinisikan secara luas sebagai metode untuk mengidentifikasi, menganalisis, dan melaporkan pola dalam bentuk tema dalam sebuah teks (Snyder, 2019).

\section{HASIL DAN PEMBAHASAN}

\section{Perkembangan Konsep Ecological City (Ecocity)}

Ecocity merupakan konsep kota yang berkembang seiring dengan perkembangan perspektif sejarah ekologi kota dan kompleksitas permasalahan lingkungan kota. Ecocity 
diharapkan dapat menjadi konsep yang mampu menjawab tantangan isu lingkungan kota dan dianggap penting dengan pertimbangan :

a. Ecocity pada awal dikembangkan merupakan model pemukiman manusia yang memiliki struktur dan fungsi ekosistem alami yang mandiri dan berkelanjutan. Konsep tersebut mengintegrasikan keanekaragaman alam dan budaya dalam desain yang terintegrasi melalui penggunaan teknologi (Register, 2006; (Roseland, 1997).

b. Konsep Ecocity adalah konsep yang berkembang seiring dengan paradigma dan gerakan-gerakan appropriate technology (AT), community economic development (CED), social ecology, the green movement, bioregionalism dan sustainable development (Roseland, 1997).

c. Ecocity jika dibandingkan dengan bentuk kota neotraditional, urban containment, dan compact city memiliki keunggulan nilai di kriteria ecological design, dan penyediaan energi terbarukan (Y. R. Jabareen, 2006).

d. Ecocity merupakan bentuk kota yang menitikberatkan pada konsep evolusi, coexistence, adaptasi dan resiliensi masyarakat dalam struktur dan fungsi kota, efisiensi penggunaan energi, upaya mengurangi kerusakan terhadap alam dan menciptakan attractive environments bagi masyarakat (Register (2006), (Roseland, 1997), (Gaffron \& Skala, 2005), (Hes \& Bush, 2018).

Di dalam konsep Ecocity terdapat 4 pilar penting yang dikembangkan yaitu urban design, bio-geophysical conditions, socio-cultural features, ecological imperatives yang didukung oleh 18 standar untuk mengukur pencapaian kondisi ecocity (Ecocity Builders, 2016). Konsep ecocity dikaji berdasarkan perkembangan baik secara teoritis maupun praktek yang telah berkembang sejak konsep tersebut digagas (Gambar 2.1) sebagai berikut

1. Secara teoritis konsep ecocity dinyatakan oleh para ahli sebagai berikut :

a. Richard Register (1987) merupakan pendiri Ecocity Builders, sebuah organisasi nirlaba yang berbasis di Berkley, California mendefinisikan ecocity sebagai pemukiman manusia dengan model struktur dan fungsi ekosistem alami yang mandiri dan berkelanjutan. Pengertian ini menitikberatkan pada upaya untuk menjaga keseimbangan ekosistem di dalam proses konsumsi dan produksi. Dalam makna tersebut, sistem kota harus seimbang dan tidak ada sumber daya yang habis atau diekstraksi pada tingkat yang lebih tinggi 
daripada yang diciptakan kembali oleh alam. Pengertian tersebut mengacu pada kondisi kota harus netral secara ekologis di setiap subsistem kota. Ecocity muncul sebagai reaksi terhadap krisis kondisi kota sebagai upaya pemikiran pentingnya pembangunan kembali ruang melalui prinsip ekologi. Prinsip tersebut mencakup pertimbangan peran kota dan evolusi peradaban kota. Faktor kunci evolusi kota yaitu kepadatan, keanekaragaman, bentuk dan fungsi kota serta kesadaran masyarakat rebuilding dan rethinking di dalamnya; serta memahami kota sebagai living organism.

b. Pada tahun 1997, M. Roseland, seorang profesor di Universitas Simon Fraser di British Columbia, menerbitkan artikel dimensi ecocity dan membahas asalusul Ecocity. Beliau mengkaji evolusi penerapan konsep ecocity selama 10 tahun dalam fokus dimensi dan orientasi yang terjadi. Beliau juga berpendapat adanya pendekatan lain untuk mendefinisikan "sustainable community" yaitu menetapkan kondisi yang diperlukan bagi masyarakat secara berkelanjutan melalui penggunaan lahan yang efisien, pengurangan konsumsi, peningkatan kemampuan hidup, dan tata kelola yang berkelanjutan.

c. Pada perkembangan selanjutnya, Duncan Crowley membahas bahwa sudah saatnya global cities bertransformasi menjadi ecocity dengan hipotesa bahwa perubahan iklim membutuhkan solusi ekologi, perpetual growth akan mempengaruhi kehidupan manusia sehingga dibutuhkan de growth baik melalui pandangan anti maupun post capitalist, serta dibutuhkan creative descent sebagai strategi kota yang berkaitan dengan adanya new cultural stories (Crowley, 2019).

2. Gambaran mengenai perkembangan praktek ecocity secara global dilakukan melalui telaah literatur yang dilakukan oleh Simon Joss (2011 dan 2013), Rapoport (2011), dan Mei-Chih (2015).

a. Joss (2010) melihat praktek Ecocity yang ada menunjukkan pengembangan skala besar, yang melibatkan berbagai sektor sistem perkotaan, didukung oleh kebijakan dan tata kelola. Pada pembaharuan data tahun 2011 menunjukkan dari sisi kebijakan adanya international knowledge transfer, carbon discourse, smart technology dan environmental modernization'. 
b. Rapoport (2011) memilih enam inisiatif ecocity dari daftar Joss serta mengidentifikasi dan membandingkan karakteristik inisiatif tersebut. Hasilnya menunjukkan bahwa persamaan karakteristik terletak pada fokus tujuan kelestarian lingkungan dengan pembahasan keberlanjutan sosial dan ekonomi yang masih minim serta kebutuhan desain dan perencanaan kota yang berkelanjutan. Perbedaan praktek yang terjadi terletak pada pemangku kepentingan yang menjalankan inisiatif serta fokus implementasi. Ada inisiatif yang dijalankan oleh pemerintah, aktivis lokal dan entitas swasta.

c. Praktek ecocity di Asia ditunjukkan oleh Mei-Chih hu et al yang mengkaji tiga kota yaitu Penghu di Taiwan, Seoul di Korea Selatan, dan Tianjin China yang menjelaskan adanya empat aspek mengubah penerapan ecocity yaitu pendekatan yang digunakan dan kebijakan nasional, keberadaan otoritas lokal yang berdedikasi, keterlibatan masyarakat yang kontinyu, dan kemampuan nasional dan bisnis (Hu et al., 2016).

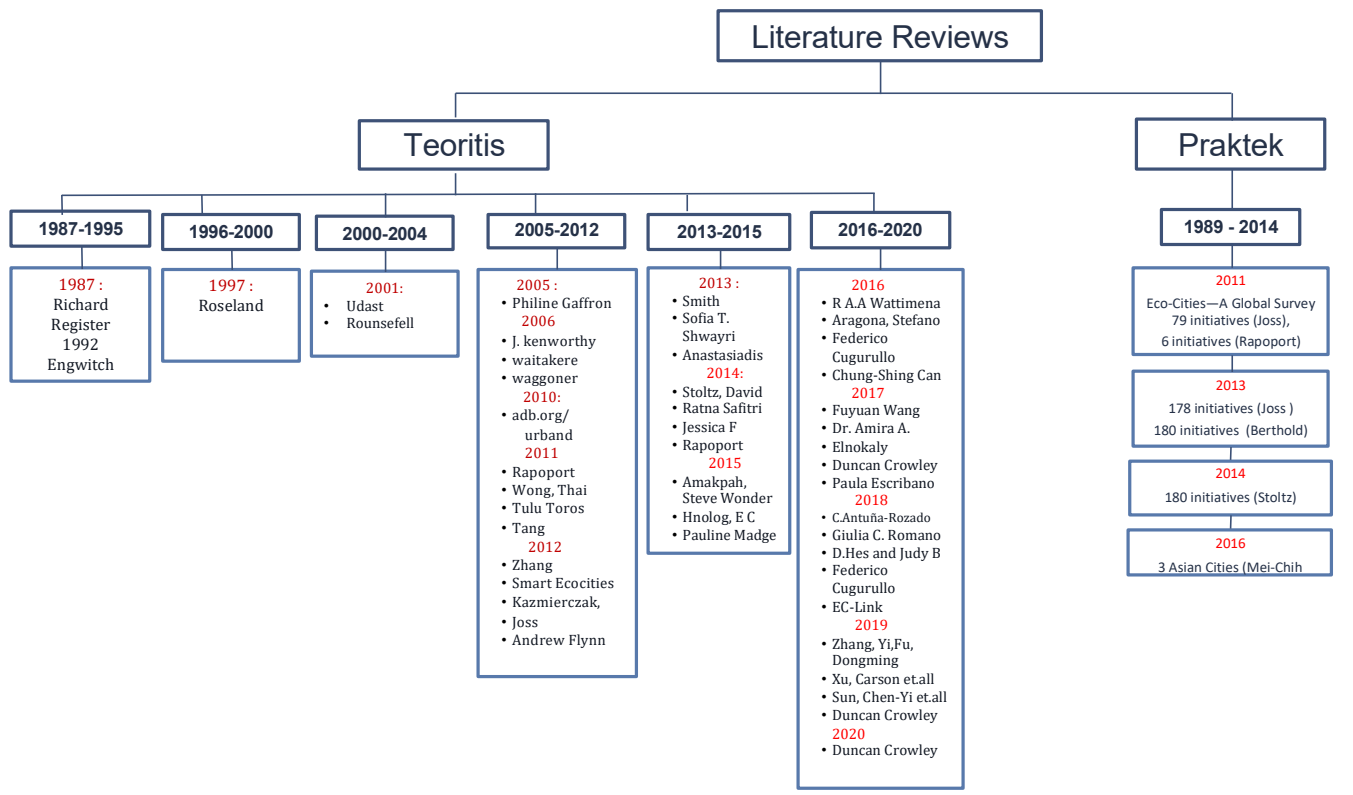

Gambar 1. Kajian Teoritis dan Praktek Ecocity

(Sintesa,2020)

Pemahaman penting yang perlu diperhatikan adalah bagaimana keberhasilan dan kegagalan praktek ecocity. Penerapan ecocity di setiap negara tidak sama baik kondisi dan fokus penanganan karena berdasarkan praktek di Eropa dan Amerika menunjukkan hal yang berbeda. Fokus transportasi, segmentasi lahan dan proses desentralisasi tidak berhasil di 
Amerika jika dibandingkan dengan Eropa yang telah berhasil menghubungkan kawasan ekonomi dengan jaringan transportasi umum yang efisien (Tang, 2013). Namun di sisi lain beberapa kota di Eropa memiliki kegagalan dalam hal ketidaksesuaian pembangunan highrise social housing (Doughlas, 2015) dan mengendalikan pertumbuhan kawasan metropolitan (Tang, 2013).

Kondisi kegagalan lainnya terjadi di China dimana pengembangan ecological design dan pengembangan energi terbarukan bagi rumah penduduk di kawasan perdesaan Huangbaiyu disebabkan oleh kurangnya pemahaman tentang kondisi lokal. Ketidaksesuaian terjadi antara konsep baru yang ditawarkan dengan kondisi ekonomi serta budaya petani lokal. Selain itu kurangnya pengawasan terhadap biaya menyebabkan harga tidak dapat dijangkau oleh mereka (The World Bank, 2009). Masalah praktek ecocity lainnya terjadi pula di Yangzhou pada hubungan antara lembaga internasional dan masyarakat lokal berupa proses transfer pengetahuan, pembelajaran, dan perubahan dalam kebijakan dan praktik lokal untuk beradaptasi dan mengimplementasikan konsep (Romano, 2018). Proses transisi masyarakat menjadi penting dari konsumsi pasif menjadi partisipasi aktif dalam menghasilkan creative practices ecocity (Hes \& Bush, 2018). Ecocity tidak hanya dapat dilakukan oleh masyarakat elit saja namun dapat dilakukan oleh masyarakat berdasarkan prinsip-prinsip regeneratif: 1) Berakar pada proses partisipatif lokal 2) Mengintegrasikan dimensi sosial, budaya, ekonomi \& ekologi dalam pendekatan keseluruhan sistem berkelanjutan 3) Secara aktif memulihkan dan meregenerasi lingkungan sosial dan alam (Crowley et al., n.d.). Kondisi kegagalan penerapan ecocity menunjukkan masih minimnya pertimbangan aspek sosial sebagai aspek penting dibandingkan dengan aspek teknologi yang mendominasi (Joss et al., 2011).

\section{Kedudukan Ecocity di dalam Konsep Urban Ecology}

Perencanaan dan pembangunan kota dalam konsep ecological city (ecocity) membutuhkan pendekatan aspek ekologi dalam mengatasi lingkungan perkotaan. Cara pandang ekologi terhadap kota berkembang dari kota sebagai organism ke cara pandang ecosystem. Di dalam perkembangan konseptualisasi kota tersebut terdapat tiga pendekatan lingkungan yang dapat digunakan yaitu pendekatan urban ecology, flows approach, dan biosocial approach (Currie \& Musango, 2017). Pada penelitian ini urban ecology digunakan sebagai pendekatan dengan pertimbangan penulis bahwa konsep ekologi kota (urban ecology) memiliki kelebihan di dalam memaknai pergeseran kota dalam perspektif ekosistem karena ekologi kota berkaitan dengan bagaimana kota memproses energi atau 
materi secara relatif terhadap lingkungan, kota sebagai tipe unik dari ekosistem alam dimana aktivitas manusia dalam pendekatan ini dipisahkan dari manusia itu sendiri dan memiliki fokus utama pada konsep, proses, gangguan, struktur dan fungsi sistem ekologi perkotaan.

Definisi urban ecology menunjukkan beberapa pengelompokkan makna yaitu :

1. Urban ecology terdiri atas ecology of cities yang merupakan metabolisme seluruh kota sebagai ekosistem dengan berbagai subsistem yang saling terkait dan ecology in cities lebih terfokus pada habitat di dalam kota dan bagaimana kondisi habitat tersebut dapat mengubah atau menggerakkan struktur dan fungsi sistem ekologi (Hall \& Balogh, 2019).

2. Urban ecology terdiri atas (Doughlas, 2015):

- The ecology of health in urban areas : kota terdiri dari habitat bagi manusia dan vektor penyakit dan termasuk di dalamnya peran alam perkotaan dalam mendukung kesejahteraan manusia.

- Ecology in towns and cities: daerah perkotaan sebagai tempat habitat bagi satwa liar, tanaman, dan organisme lainnya.

- The ecology of cities as a whole: aliran energi, air, material, dan informasi ke dalam dan ke luar daerah perkotaan serta dampak internal dan eksternal; perbedaan dalam wilayah perkotaan; pedesaan-perkotaan; dan analisis sistem ekologi-sosial perkotaan yang kompleks

- Ecology for cities: meningkatkan layanan ekosistem yang disediakan melalui infrastruktur hijau perkotaan dalam rangka membangun ketahanan terhadap perubahan, termasuk perubahan lingkungan, dan untuk meningkatkan keberlanjutan perkotaan dan meningkatkan kohesi masyarakat.

Inti ekologi perkotaan (Urban ecology) adalah studi tentang struktur dan fungsi biotik dan a biotik kota. Struktur ekologi perkotaan berupa jumlah, ukuran, komposisi, dan sifat komponen, dan terdiri dari komponen a biotik dan biotik. Fungsi adalah proses bagaimana spesies beradaptasi atau berevolusi di lingkungan perkotaan. Jika dilihat dari perkembangan urban ecology dan ecological city menunjukkan pada awalnya perkembangan urban ecology menunjukkan fokus perhatian pada organisme di dalam kota mencakup hewan, tumbuhan hingga awal periode 1970an. Perkembangan selanjutnya fokus perhatian pada kota sebagai ekosistem dan pengetahuan multi disiplin dan integratif dengan memasukkan komponen manusia lebih lanjut. Perkembangan ecocity searah dengan awal perkembangan urban ecology dimana sebagai dasar dari bentuk-bentuk estetis dalam city 
design desain kota yang merupakan city beautiful movement. Pada perkembangan berikutnya, upaya perbaikan kualitas lingkungan kota akibat perkembangan kawasan industri menghasilkan ecological principles dan teknologi hijau untuk mendukung ecological design suatu kota. Dari sisi sosial masyarakat semakin berkembangnya environmental movement sebagai bentuk menyikapi pembangunan kota yang pesat dan pengaruh globalisasi.

Perkembangan ecocity dalam sistem ekologi perkotaan (urban ecological system) berkaitan dengan kota sebagai sistem yang didominasi manusia dengan kondisi Pertama, manusia mendominasi ekosistem bumi. Kedua, pengembangan model yang lebih realistis untuk sistem ekologi akan mengarah pada keberhasilan yang lebih besar dalam menemukan solusi untuk masalah lingkungan. Ketiga, konsep ekologi yang relatif baru yaitu kota sebagai ekosistem dimana manusia di dalamnya. Mempelajari kota sebagai ekosistem dalam paradigma baru ilmu ekosistem (Grimm et al., 2008) meningkatkan kesadaran kolektif para ahli ekologi mengenai ekosistem perkotaan yang berkontribusi terhadap pengembangan konsep yang berlaku bagi semua ekosistem. Oleh karena itu perkembangan tersebut menunjukkan pentingnya untuk membahas hubungan teori sosial yang mencakup persepsi individu, kebutuhan, nilai-nilai, dan pengetahuan terhadap keberlanjutan proses perencanaan melalui partisipasi secara intensif dari pemangku kepentingan terkait. Pemahaman tentang bagaimana kota bekerja dalam arti ekologis adalah menyadari fakta bahwa manusia hidup di dalamnya dan harus bergantung pada pengelolaan yang tepat untuk mempertahankan kualitas hidup yang dapat diterima untuk masa mendatang.

Ecocity jika dilihat berdasarkan teori, praktek dan pendekatan urban ecology yang telah diuraikan sebelumnya, dapat disimpulkan sebagai konsep yang menyeimbangkan metabolisme kota (ecology of cities) pada kemandirian struktur dan fungsi ekosistem alami dimana manusia berperan di dalam menentukan proses adaptasi dan perkembangan kota. Integrasi manusia sebagai aspek sosial dengan metabolisme kota berkaitan dengan interaksi manusia dengan ekosistem kota (Gambar 2). Proses metabolisme kota menjadi dasar penting di dalam menyediakan ecology for cities berupa ecosystem services dan green infrastructure (ecological design, energi terbarukan). Pendekatan sosial sebagai upaya untuk memahami tindakan dan pengaruh manusia terhadap ekosistem dalam kerangka urban ecology penting untuk menggunakan pendekatan integrasi aspek sosial dan ekologi (socio-ecological). 


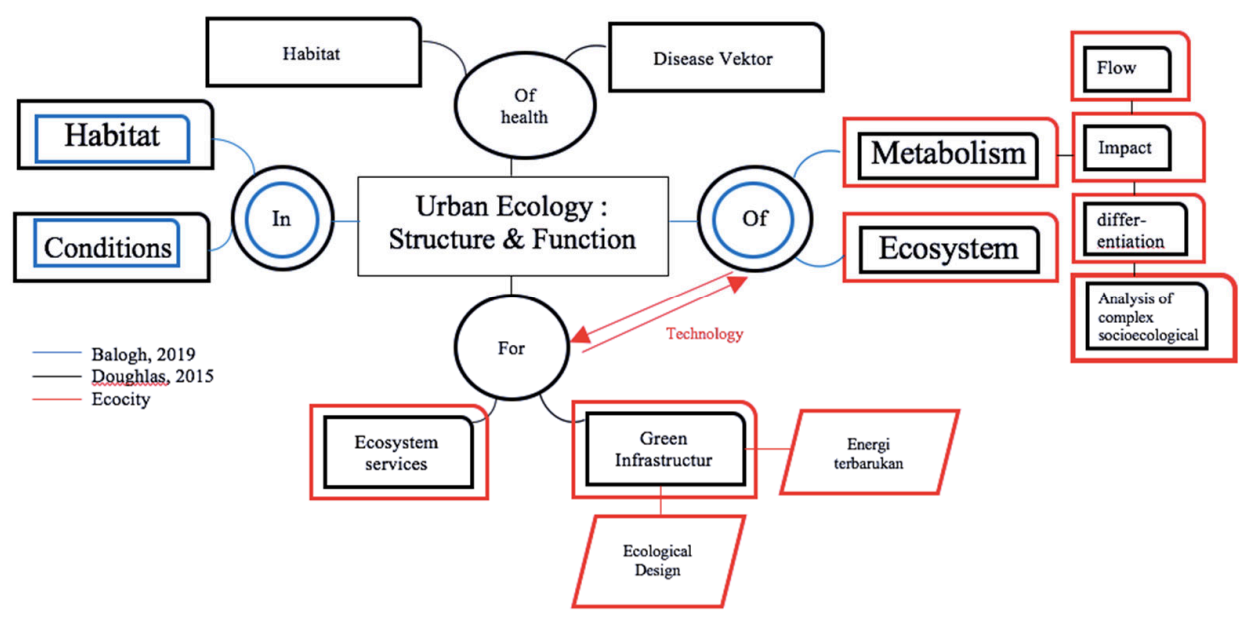

Gambar 2. Konsep Ecocity dalam Urban Ecology

(Sintesa, 2020)

\section{Kedudukan Ecocity di Dalam Konsep Kota Berkelanjutan}

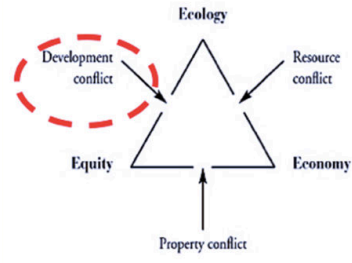

(1)

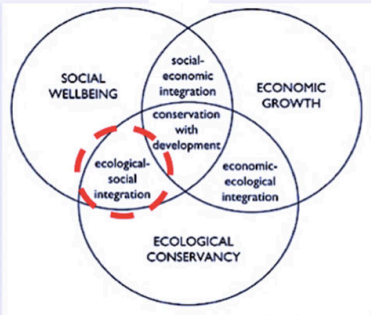

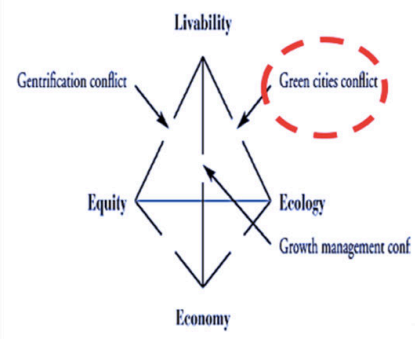

(2)

Keterangan :

1. Value sustainable, (Campbell, 1996).

2. Gap Value The sustainability/livability prism: Value 2004)

3. Konsep Analysis (Jabareen, 2008).

4. Struktur konsep berkelanjutan tahun 1992 (United Nations, 2014)

(4)

Ongoing process of resolving three conflicts (Campbell,2016)

(5)
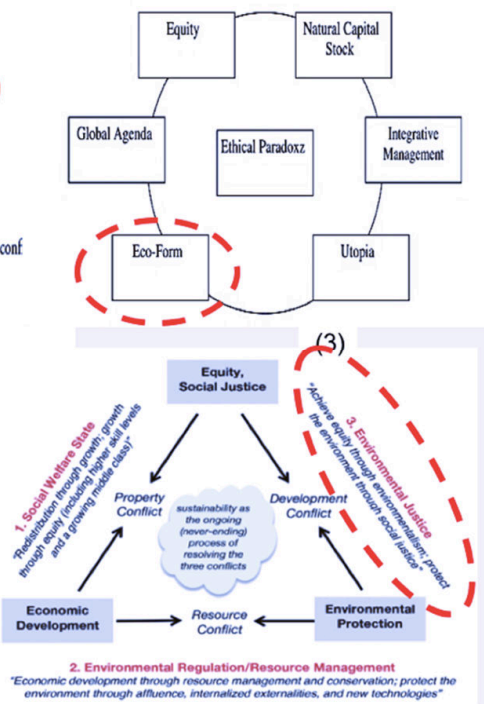

Gambar 3. Ecocity dalam Perkembangan Konsep Pembangunan Berkelanjutan (Disarikan dari berbagai literatur, 2019)

Eco-forms dalam ecocity diwujudkan dalam bentuk "Sustainable' design" dimana energi didesain untuk disediakan secara efisien dalam kurun waktu jangka panjang. Sustainable development merupakan salah satu dimensi eco city (Roseland, 1997) sebagai kebutuhan saat ini dengan memperhatikan kemampuan generasi masa depan untuk dapat memenuhi kebutuhan.

Berdasarkan perkembangan dari sisi teori, praktek dan model keberlanjutan maka jika dikaitkan dengan perkembangan implementasi ecocity sebagai kota modern di negara 
maju telah mengarah kepada implementasi relasi ruang yang kompleks menggunakan teknologi namun masih minim di dalam mengeksplorasi aspek sosial. Kondisi tersebut berbeda dengan arah konsep kota berkelanjutan yang telah berubah dari konsep teoretis menjadi berfokus pada upaya lokal. Aspek keberlanjutan masyarakat harus didefinisikan dari perspektif komunitas lokal namun dapat pula melalui penentuan kondisi bagi mereka (Roseland, 1997). Oleh karena itu value masyarakat lokal penting untuk diperhatikan di dalam perencanaan konsep ecocity (Haberl, Helmut, Marina Fischer-Kowalski, Fridolin Karausmann, 2016)Upaya mengintegrasikan konsep ecocity yang memperhatikan aspek lokal masyarakat menjadi penting di dalam menerapkan konsep saat ini.

Keterkaitan konsep ecocity dan kota berkelanjutan berkembang adalah ecocity tidak hanya untuk melindungi kelangsungan hidup dan pembangunan hak asasi manusia kontemporer, tetapi juga untuk memastikan kelangsungan hidup dan perkembangan hak asasi manusia di masa depan, yaitu untuk mempromosikan pembangunan sosial yang berkelanjutan (sustainable social development) (Song, 2011).

Perkembangan konsep ecocity, urban ecology dan kota berkelanjutan dapat dilihat pada gambar 4.

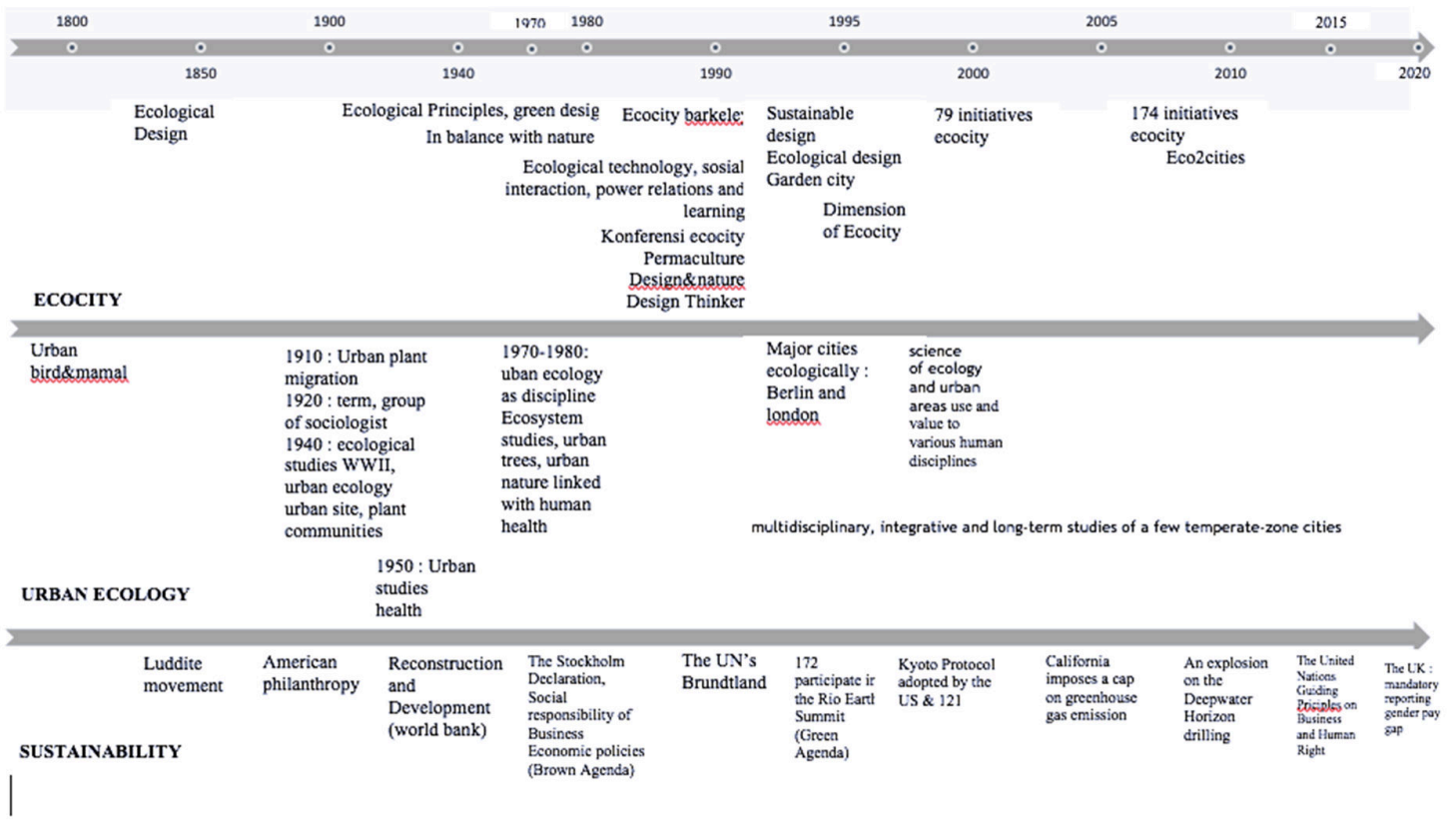

Gambar 4. Timeline Perkembangan Konsep Ecocity, Urban Ecology Dan Sustainability (Doughlas,2015; Hall\&Balogh,2019, https://corporate-citizenship.com/sustainabilitytimeline/ 


\section{IMPLIKASI KONSEP ECOCITY PADA PERENCANAAN KOTA DI INDONESIA}

Kebijakan dan Strategi Pembangunan Perkotaan Nasional (KSPPN) 2015-2045 yang telah disusun Kementerian Perencanaan Pembangunan Nasional (Bappenas), meletakkan dasar-dasar bagi pembangunan perkotaan berkelanjutan dan berdaya saing. Prinsip-prinsip pembangunan berkelanjutan dalam pembangunan perkotaan, yaitu memenuhi kebutuhan perkotaan saat ini tanpa mengorbankan pemenuhan kebutuhan generasi perkotaan masa depan (PPN/BAPPENAS, 2015). Kondisi tersebut menuntut kajian lingkungan yang berfokus pada interaksi antara organisme makhluk hidup dan lingkungan perkotaan atau yang disebut ekologi perkotaan. Salah satu pendekatan penting di dalam mengatasi permasalahan perkotaan saat ini adalah konsep ecocity dan sangat penting untuk dapat diterapkan di negara-negara Asia dan dikaji dampaknya pada masyarakat.

Beberapa program lokal dari pemerintah kota sudah mengarah pada rencana penerapan ecocity yaitu Kota Surabaya sebagai ecocity untuk mewujudkan kota yang bersih, hijau dan hemat energi yang nyaman bagi masyarakat kota. Salah satu penerapan eco city dengan penerapan konsep green building dengan cara menyelenggarakan Green Building Awareness Award bagi pengelola bangunan di Surabaya. Selain itu pengembangan konsep Bogor Eco-city, yaitu kota yang hijau, sehat, dan ramah lingkungan. Konsep tersebut didukung dengan adanya basis data dan sistem monitoring menggunakan data lokal berdasarkan data karakteristik Kota Bogor. Untuk memenuhi hal tersebut, Pusat Pengelolaan dan Peluang Risiko Iklim kawasan Asia Tenggara dan Pasifik (CCROM-SEAP) Lembaga Penelitian dan Pengabdian kepada Masyarakat (LPPM) Institut Pertanian Bogor (IPB), bekerjasama dengan National Institute for Environmental Studies (NIES) Jepang mengembangkan sistem monitoring dan visualisasi inovatif. Sistem tersebut dikembangkan melalui program instalasi demo sistem penggunaan energi di Kota Bogor serta simulasi skenario Bogor eco-city masa depan berdasarkan parameter informasi dan emisi Gas Rumah Kaca kota spesifik Kota Bogor.

Berdasarkan uraian kedudukan ecocity di dalam konsep ekologi kota dan kota berkelanjutan menunjukkan bahwa konteks masyarakat lokal di Indonesia akan berkontribusi di dalam mendukung keberlanjutan lingkungan lokal (social ecology). Pendekatan ecocity mengembangkan pembangunan lingkungan kota secara unik yang merefleksikan kondisi lokal ekologi untuk mendukung daya tangguh dan masyarakat kota yang berkelanjutan. Daya tangguh dalam arti sumber daya ecocity yang digunakan harus tersedia secara lokal di ekosistem terdekat dan pengembangan ecocity seharusnya tidak 
hanya merefleksikan ketersediaan secara lokal tetapi penggunaan sumber daya tersebut dilakukan secara berkelanjutan.

\section{KESIMPULAN DAN REKOMENDASI}

Konsep ecocity dengan pendekatan ekologi kota (urban ecology) dipahami sebagai fungsi dan struktur kota yang sangat memperhatikan aspek lokal masyarakat tidak hanya sebagai obyek yang homogen melainkan berbagai peran di dalam menentukan fungsi kota yang semakin dinamis berdasarkan proses adaptasi dan perkembangan yang terjadi. Dalam konteks kota berkelanjutan menunjukkan konsep ecocity berupa hubungan antara kondisi lokal sebagai human dengan kondisi lingkungan (nature) akan menentukan karakteristik lokal sebagai ukuran keberlanjutan sosial serta menjadi tantangan penerapan ecocity di negara berkembang.

Penerapan ecocity jika dilihat dari kondisi kota-kota di Indonesia tidak hanya dipilah berdasarkan bentuk dan skala kawasan seperti kota baru, perluasan dan peremajaan kota, unit lingkungan dan lain-lain seperti yang terjadi di negara-negara lain karena Indonesia memiliki kondisi sosial kultural terhadap alam (social ecology) berbeda yang dipengaruhi oleh berbagai faktor sosial lainnya. Perbedaan kondisi kultural tersebut akan memberikan warna yang berbeda di dalam setiap dimensi sosial dalam ekologi kota (urban ecology) serta akan berpengaruh terhadap keseimbangan metabolisme kota (ecology of cities) dalam menghasilkan ecology for cities melalui penggunaan teknologi, proses adaptasi masyarakat dan perkembangan kota.

Variasi karakteristik tersebut dapat mengarahkan perencana dan pembuat kebijakan untuk merumuskan pengambilan keputusan perencanaan yang menciptakan ekosistem seimbang sebagai perbedaan karakter di dalam konsep ruang dan situasi spesifik perencanaan yang terkait dengan upaya pelestarian lingkungan, memperbaiki fungsi ekologi dan kota, dan memberikan ecosystem service yang terbaik dan berkelanjutan.

\section{DAFTAR PUSTAKA}

Campbell, S. D. (2016). The Planner's Triangle Revisited: Sustainability and the Evolution of a Planning Ideal That Can't Stand Still. Journal of the American Planning Association, 82(4), 388-397.

Crowley, D. (2019). Adapt or Die. Kicking our Oil Addiction to create Post-Capitalist Community led Ecocities Duncan Crowley - PhD student: Architecture of Contemporary Metropolitan Territories (ISCTE,Lisbon).May. 
Crowley, D., Crowley, D., \& Ecocity, E. E. (n.d.). (2020). Exploring Ecocity transformation possibilities in Lisbon with three Community-Led Initiatives; Bela Flor, Ajuda, Marvila (BAM).

Currie, P. K., \& Musango, J. K. (2017). African Urbanization: Assimilating Urban Metabolism into Sustainability Discourse and Practice. Journal of Industrial Ecology, 21(5), 1262-1276.

Doughlas, I. (2015). Urban Ecology: An Introduction. New York: Routledge.

Ecocity Builders. (2016). Ecocitity Focus Lab. June, 14.

Gaffron, P., \& Skala, F. (2005). Ecocity Book I: A better place to live.

Godschalk, D. R. (2004). Land use planning challenges: Coping with conflicts in visions of sustainable development and livable communities. Journal of the American Planning Association, 70(1), 5-13.

Grimm, N. B., Grove, J. M., Pickett, S. T. A., \& Redman, C. L. (2008). Integrated approaches to long-term studies of urban ecological systems. Urban Ecology: An International Perspective on the Interaction Between Humans and Nature, 50(7), 123 141.

Haberl, Helmut, Marina Fischer-Kowalski, Fridolin Karausmann, V. W. (2016). Social Ecology. In Social Ecology.

Hall, M., \& Balogh, S. B. (2019). Understanding Urban Ecology: An Interdisciplinary Systems Approach.

Hes, D., \& Bush, J. (2018). ECO-CITIES (D. \& J. B. Hes, Ed.). Palgrave Macmillan.

Hu, M. C., Wadin, J. L., Lo, H. C., \& Huang, J. Y. (2016). Transformation toward an ecocity: Lessons from three Asian cities. Journal of Cleaner Production, 123, 77-87.

Jabareen, Y. (2008). A new conceptual framework for sustainable development. Environment, Development and Sustainability, 10(2), 179-192.

Jabareen, Y. R. (2006). Sustainable urban forms: Their typologies, models, and concepts. Journal of Planning Education and Research, 26(1), 38-52.

Joss, S., Cowley, R., \& Tomozeiu, D. (2013). Towards the "ubiquitous eco-city": An analysis of the internationalisation of eco-city policy and practice. Urban Research and Practice, 6(1), 54-74.

Joss, S., Tomozeiu, D., \& Cowley, R. (2011). Ecocity Profiles (Issue September).

Mei-Chih Hu, J. L.-C.-Y. (2015). Transformation toward an eco-city : lessons from three Asian cities . Journal of Cleaner Production (2015),

Mayona, E. L. (2021). Pergeseran Makna Kota Berdasarkan Perspektif Lingkungan. Rekaloka.

PN/BAPPENAS. (2015). Grand Design Pembangunan Kota Baru dan Penataan Kota di Indonesia. Jakarta.

Richard Register.(2006). EcoCities_Rebuilding Cities in Balance with Nature (Revised Edition)-New Society Publishers. (n.d.).

Romano, G. C. (2018). Organisational Learning Analysis and Transfer of "Eco-City" Concepts to China. March, 37-43.

Roseland, M. (1997). Dimensions of the eco-city. Cities, 14(4), 197-202.

Snyder, H. (2019). Literature review as a research methodology: An overview and guidelines. Journal of Business Research, 104(July), 333-339.

Song, Y. (2011). Ecological city and urban sustainable development. Procedia Engineering, $21,142-146$.

Sutriadi, R. (2018). Perencanaan Kota Abad 21 : Inovasi dan Tujuan Pembangunan Berkelanjutan. Bandung: ITB Press. 
Tang, Z. (2013). Eco-city and Green Community. In Journal of Chemical Information and Modeling (Vol. 53, Issue 9).

The World Bank. (2009). Sino-Singapore Tianjin Eco-City: A Case Study of an Emerging Eco-City in China. 168. http://www-wds.worldbank.org

The World Bank. (2010). Eco2Cities : Ecological Cities as Economic Cities. Retrieved from www.worldbank.org/eco2.

United Nations, D. o.-b.-H. (2014). http://esa.un.org/ unpd/wup/Highlights/WUP2014Highlights.pdf

WEF. (2017). Harnessing Public-Private Cooperation to Deliver the New Urban Agenda. February. 